\title{
ELK ISLAND NATIONAL PARK
}

ROSS J. CHAPMAN, Chief Park Interpreter, Elk Island National Park, Site 4, R.R. 1, Fort Saskatchewan, Alberta. T8L 2N7

Elk Island, with its $194 \mathrm{~km}^{2}$, is truly an island in the midst of a sea of farmland and development. A mere $32 \mathrm{~km}$ to the west lies Edmonton, the heartland of industrial Alberta, with its gleaming skyscrapers and refineries supplying lifeblood oil to western Canada. This year, along with the 30 other national parks, it celebrates 100 years of heritage conservation.

Five local men back in 1905 had enough courage and foresight to fight presures to hunt and exterminate the last of the Beaver Hills Elk. The Elk, down in number to about 24 , were, in the winter of 1905 , to fall to the rifles of men. But the five men from the Edmonton/Fort Saskatchewan area petitioned the Federal Government to set aside a small tract of land surrounding Astotin Lake. The government would enclose the land in a fence and Elk would be driven inside. As a result of their efforts, this fenced enclosure of some $41 \mathrm{~km}^{2}$ became Elk Island Park in 1906, the first Federal Wildlife Sanctuary in Canada.

Elk Island has been the foster parent to generations of rare animals and birds. Since it is the only completely fenced national park in Canada, these species can be monitored very closely.

In 1907, after the Canadian Government purchased the Pablo herd of Plains Bison in Montana, these animals were transported by railway car to Elk Island, where they were kept until a fence was erected around Wainwright Buffalo Park. The Pablo herd, numbering just over 700 animals, was the last large herd of Plains Bison in North America, and the Plains Bison was facing certain extinction at this time.

A few years after the Plains Bison had arrived at Elk Island, the fence was finished at Wainwright. The bulk of the herd was transported to Wainwright, but a few eluded capture. Their descendants remain at Elk Island today. The present herd of about 400 Plains Bison at Elk Island are pure and disease free, and form the foundation herd for many other herds in North America.

Elk Island's wildlife management role, however, was to spread beyond its boundaries. In the mid-1920's, Plains Bison from Wainwright Buffalo Park had been shipped to Wood Buffalo National Park. This resulted in hybridizatrion with, and introduction of disease into, the Wood Bison. In an effort to save the Wood Bison, a genetically pure herd was relocated to Elk Island in 1965. This herd now numbers approximately 217 individuals and is kept in a disease free area that is separated from the Plains Bison in the park by a 7 foot high fence and a four-lane highway. Careful management by park wardens has increased this subspecies to the extent that soon it may no longer be considered endangered.

Elk Island has been the scene for several re-introductions. The fur trade drastically reduced the populations of fur-bearing animals in the Elk Island area. The Beaver, for example, was completely exterminated. In the 1920's the park re-introduced the Beaver by releasing one pair. Unfortunately, sexing a beaver is difficult. After several years the park Beaver population remained unchanged, and it became clear that the "couple" was of the same sex. In 1941 another transplant was carried out, this time with seven Beaver from Banff National Park. The transplant was so successful that beaver soon colonized nearly every lake and pond in the park. Today the beaver population in Elk Island numbers over 2000.

Since this area of $194 \mathrm{~km}^{2}$ of very rich, highly productive land is enclosed by a 


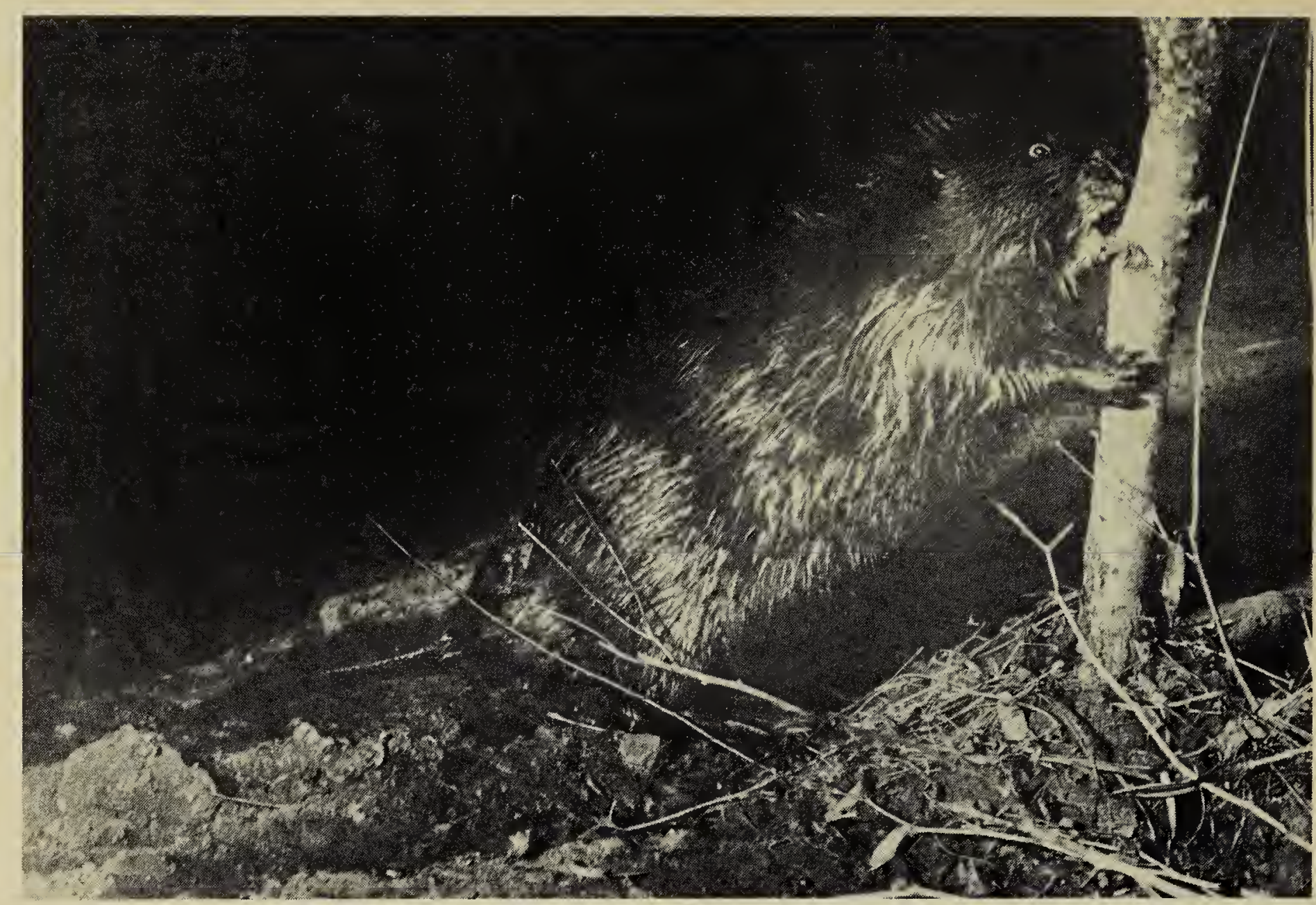

Beaver

Hans Dommasch

fence, and has an extremely dense wildlife population, Elk Island is one of the most intensively managed national parks in Canada. By enclosing the first small herd of Elk behind a 7-foot high fence, an artificial barrier was created that continues to influence the management of large mammals today. The fence is responsible for two things: it keeps some animals in, and others it keeps out. This, combined with the lack of predators such as wolves and bears, has made necessary very intensive managements activities. One of the first, almost overwhelming, problems park wardens encountered was a shortage of food for the wildlife. They responded by building an abbatoir in the park in 1928, and reducing overpopulated herds of large mammals through controlled slaughter.

Until the mid-1960's, plains bison and elk populations were controlled through slaughter. However, starting in 1967, the first commercial sale of Plains Bison took place, a practice which continues to this day. Elk are no longer slaughtered, but are trapped and donated to provincial governments and public institutions for relocation. Parks, zoos and nature reserves have received some of the surplus animals from the Elk Island herd. As a result of this program, Elk, Plains Bison and some Wood Bison have been relocated all over North America, and even abroad to countries like New Zealand.

Unfortunately, moose are still slaughtered peridocally to prevent mass starvation, disease and severe damage to their habitat due to overbrowsing. New techniques being developed, however, may soon see surplus moose join the elk and bison in being relocated to new homes outside the park.

Elk Island is more than just wildlife management, however. It is a part of the Beaver Hills that has been set aside for present and future generations of Canadians. Millions of years ago a huge chunk of ice was stranded on a bedrock high, and melted to form the dead ice moraine terrain that characterizes Elk Island today. The 
bumps and hollows of Elk Island and the Beaver Hills contrast sharply with the surrounding flat landscape. In the hollows a glacial silt layer traps water. As a result, nearly 20 percent of Elk Island's landscape is pocketed with wetlands.

Elk Island's knob and kettle terrain gives rise to a variety of landscape types that succeed one another. There are wetland communities at Elk Island showing stages of succession from open water to dry land. In the cattail shoreline, emergent plants such as cattails and arrowheads are the first visible sign that the cattail shoreline is drawing itself around the open waters of Elk Island's lakes. In the cattail shoreline many animals thrive, such as the Muskrat, Red-winged Blackbird, Blue-winged Teal, damsel flies and snails.

The rich nutrients from run-off and the surrounding dark soils contribute to the abundant lake and pond life at Elk Island. During the height of summer, the waters are so thick with duckweed and other minute plants and animals that visibility in the water is greatly reduced. Leeches, fresh water snails, Water Boatmen, Fat-head Minnows and sticklebacks thrive in the nutrient charged water. In turn, these eutrophic waters become home to thousands of waterfowl, including coots, common loons, red-necked grebes, and a host of ducks and geese.

In a sedge meadow you will often see a central cluster of cattails. The roots of the sedge hinder the establishment of other species. Frequently, the meadows flood in spring. In winter, bison are often see grazing in sedge meadows.

Scrubland meadows occur in depressions that once were ponds. There are two types of scrubland meadow at Elk Island. The wet type has several kinds of small willows and is characterized by a variety of sedges and coltsfoot. The dry type has reed grasses, which have displaced many of the sedges.

Close to 80 percent of Elk Island is covered by dryland communities. The predominant community is the poplar dominated mixedwood forest. Here the Trembling Aspen is most widespread. Birch and Balsam Poplar are of lesser importance.

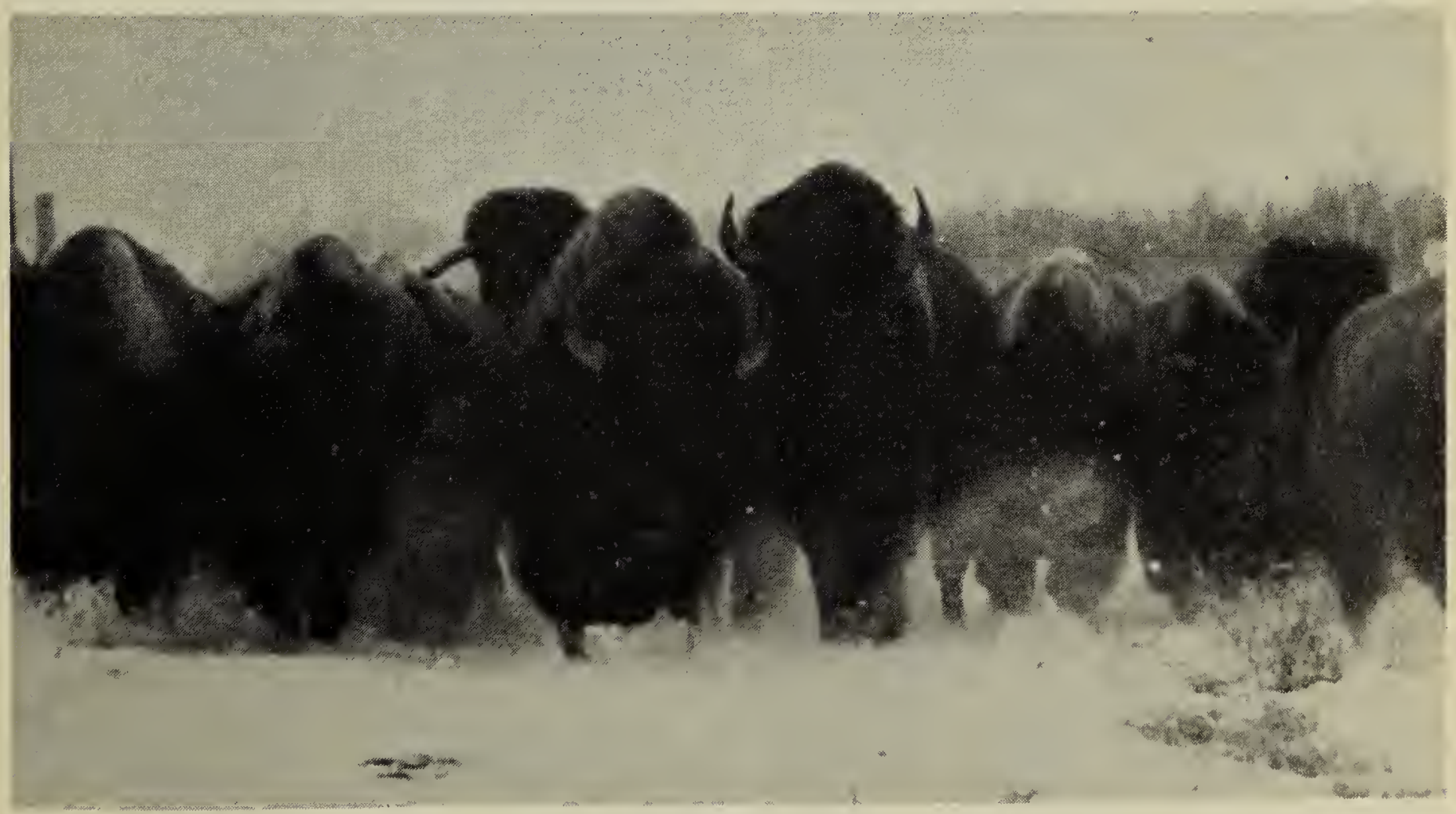

Plains Bison, Elk Island National Park

Parks Canada 
The layering of the forest community (herbs and grasses, shrubs, and trees) provides a variety of habitats for birds and mammals. Moose, Porcupine, Hoary Bat, Yellowrumped Warbler, Hairy Woodpecker and Northern Oriole frequent this community. Common plants include Pin Cherry, Saskatoon, Red-osier Dogwood, hazelnut, Prickly Rose, baneberry, Bunchberry and Sarsaparilla.

Scattered in stands throughout the park, and on the islands of Astotin Lake, is the white spruce. Birch, poplar, Wild Red Raspberry and Dwarf Mistletoe are associated with the spruce. Ruffed Grouse, Yellow-bellied Sapsuckers, Pileated Woodpeckers and Red Squirrels frequent this forest type. The island spruce are survivors of the 1895 fire that swept the park, as are the spruce remaining on north-facing slopes, where spruce seedlings commonly have the best chance of establishing themselves.

A parkland type of community is also found in Elk Island. This community is a blend of grassland and open stands of Trembling Aspen. Outside the park, Rough Fescue and aspen are interspersed in the aspen parkland, however, owing to fire suppression and heavy grazing by park ungulates, the fescue grasslands within the park have been modified.

Elk Island is also a place for people; it has an annual visitation rate of close to 500,000 people. With over $90 \mathrm{~km}$ of trails, it has become the most popular area close to Edmonton for cross-country skiing. In the summertime, because it is less than an hour's drive from Edmonton, Elk Island is frequently included in a tour of the greater Edmonton area. The huge density of large mammmals in the park (over 2000), and its 217 species of birds, make the park popular with nature lovers.

An interpretive programme is offered in the park seven days a week at the new Astotin Interpretive Centre, located in the Sandy Beach area. This year the emphasis of the interpretive programme is on the 1985 Centennial of parks in Canada.

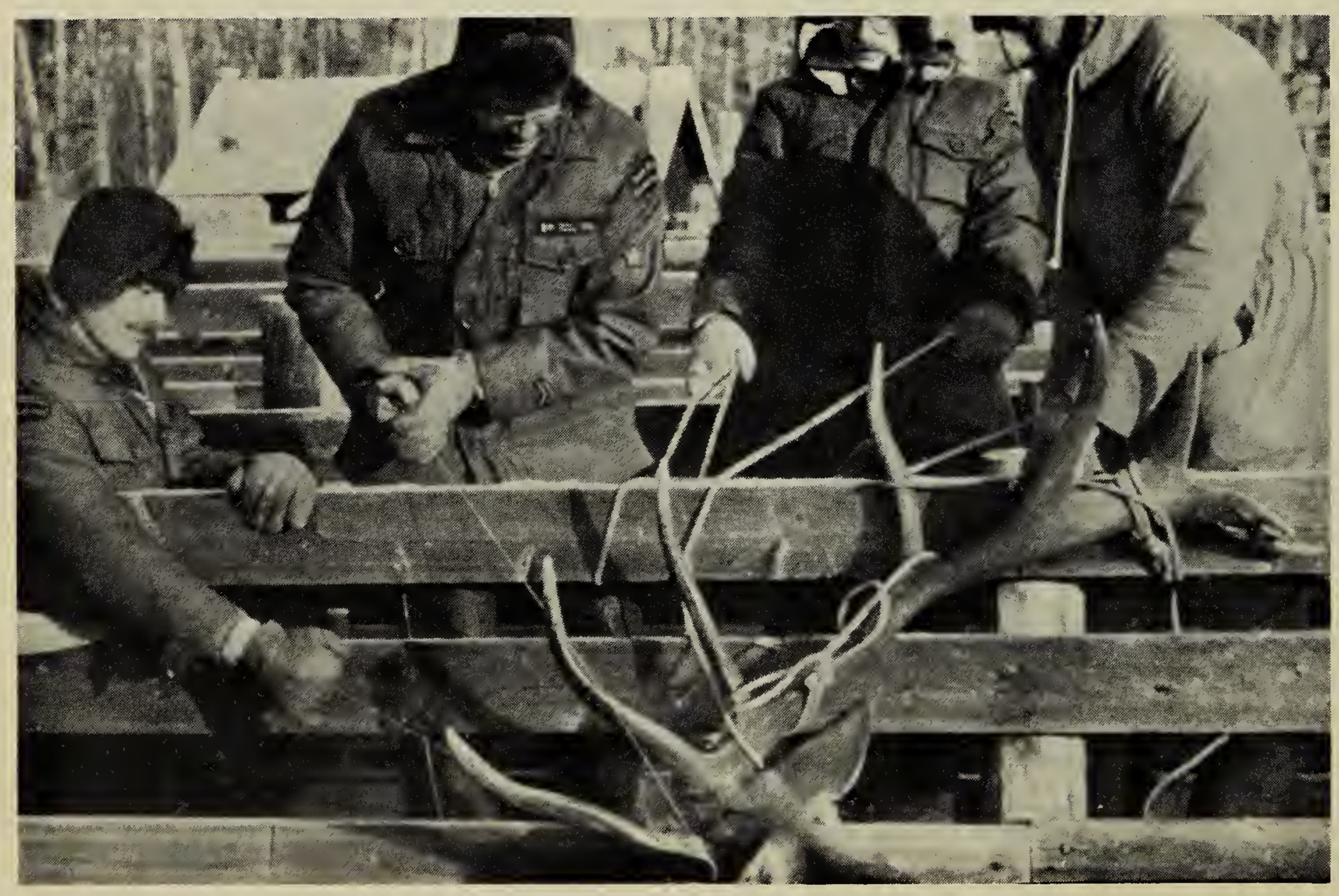

Handling Elk, Elk Island National Park

Parks Canada 